\title{
International Archives of
}

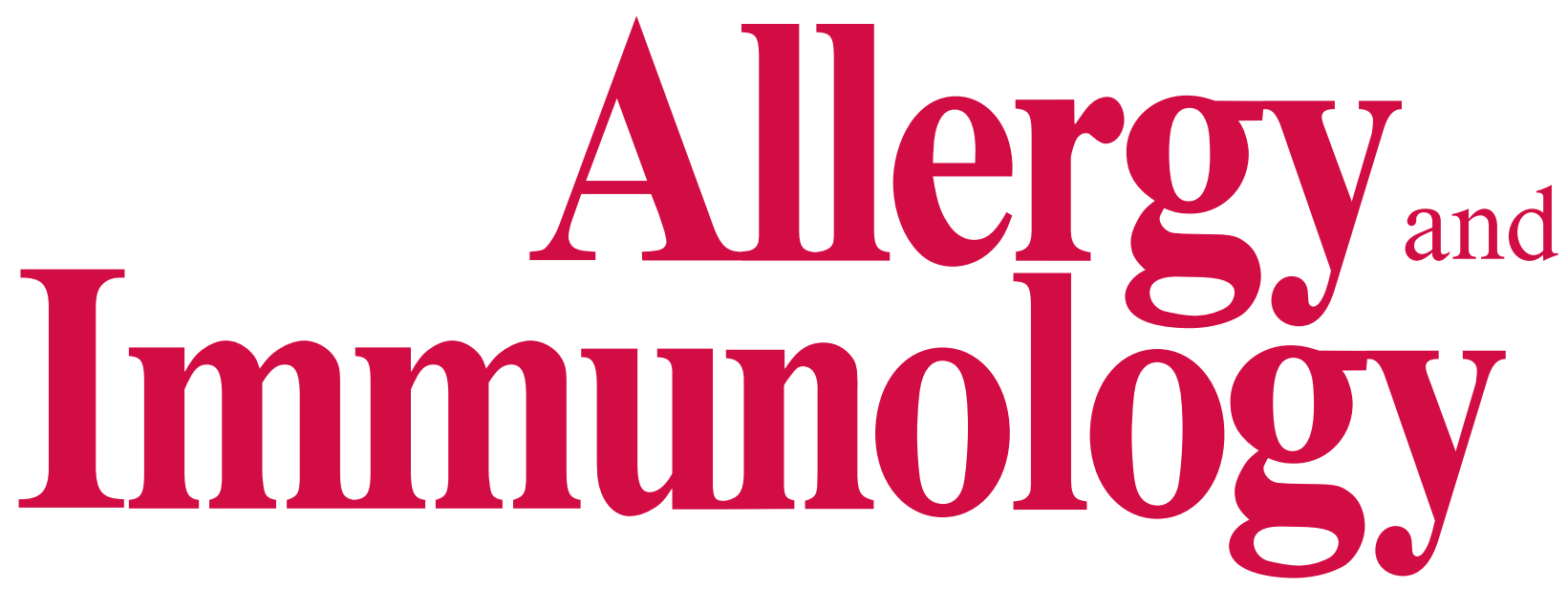

Official Journal of the

Collegium Internationale Allergologicum<smiles>c1ccc(C23CC4CC(CC(C4)C2)C3)cc1</smiles>

\section{Editorials}

1 Mechanisms of Aspirin-Intolerant Asthma: Identifying Inflammatory Pathways in the Pathogenesis of Asthma

Neighbour, H. (Hamilton, Ont.)

3 Big-Time Sensitization Rates in Young Germans: Big Numbers - Big Risks - Big Confusion?

Kleine-Tebbe, J. (Berlin)

\section{Molecules and Cells in Allergy}

5 IL-25 and IL-25 Receptor Expression on Eosinophils from Subjects with Allergic Asthma

Tang, W. (Hamilton, Ont./Shanghai); Smith, S.G.; Beaudin, S.; Dua, B.; Howie, K.; Gauvreau, G.; O’Byrne, P.M.

(Hamilton, Ont.)
Mechanisms of Allergy

11 Histamine Downregulates the Th1-Associated Chemokine IP-10 in Monocytes and Myeloid Dendritic Cells

Glatzer, F.; Mommert, S.; Köther, B. (Hannover);

Gschwandtner, M. (Hannover/Vienna); Stark, H.

(Frankfurt am Main/Düsseldorf); Werfel, T.; Gutzmer, R. (Hannover)

20 Analysis of Filaggrin Mutations and Expression in Corneal Specimens from Patients with or without Atopic Dermatitis

Lapp, T. (Freiburg im Breisgau/London); Auw-Haedrich, C.;

Reinhard, T. (Freiburg im Breisgau); Evans, R. (London); Rodríguez, E.; Weidinger, S. (Kiel); Jakob, T.

(Freiburg im Breisgau)

25 Supplementation with Probiotics in the First 6 Months of Life Did Not Protect against Eczema and Allergy in At-Risk Asian Infants: A 5-Year Follow-Up

Loo, E.X.L.; Llanora, G.V.; Lu, Q.; Aw, M.M.; Lee, B.W.; Shek, L.P. (Singapore)

(Continued on inside front cover) 


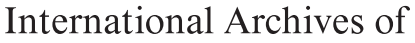 \\ Allergy
Immunologd}

(Continued from front cover)

Clinical Allergology

29 Tolerability and Clinical Outcome of Coseasonal Treatment with Escherichia coli Strain Nissle 1917 in Grass Pollen-Allergic Subjects

Dölle, S.; Berg, J.; Rasche, C.; Worm, M. (Berlin)

36 A Computerized Asthma-Specific Quality of Life: A Novel Tool for Reflecting Asthma Control and Predicting Exacerbation

Kim, M.-A.; Ye, Y.-M. (Suwon); Park, J.-W.; Lee, J.-H. (Seoul); Lee, S.-K. (Busan); Kim, C.-W. (Incheon); Jung, K.-S.; Kim, J.-H. (Pyeongchon); Yoo, H.-S.; Kim, S.-H.; Shin, Y.S.; Nahm, D.-H.; Park, H.-S. (Suwon) on behalf of the Premier Researchers Aiming New Era in Asthma and Allergic Diseases (PRANA) Study Group

43 Effects of Airborne Birch Pollen Levels on Clinical Symptoms of Seasonal Allergic Rhinoconjunctivitis

Caillaud, D. (Clermont-Ferrand); Martin, S.; Segala, C. (Baud); Besancenot, J.-P. (Brussieu); Clot, B. (Payerne); Thibaudon, M. (Baud) on behalf of the French Aerobiology Network
51 A Randomized Controlled Trial to Assess Adherence to Allergic Rhinitis Treatment following a Daily Short Message Service (SMS) via the Mobile Phone

Wang, K.; Wang, C.; Xi, L.; Zhang, Y.; Ouyang, Y.; Lou, H.; Zhang, W.; Zhang, L. (Beijing)

59 Objectifying the Conjunctival Provocation Test: Photography-Based Rating and Digital Analysis Dogan, S.; Astvatsatourov, A. (Cologne); Deserno, T.M. (Aachen); Bock, F.; Shah-Hosseini, K.; Michels, A.; Mösges, R. (Cologne)

Novel Insights from Clinical Practice

69 Cytomegalovirus Disease in Patients with Common Variable Immunodeficiency: Three Case Reports

Kralickova, P.; Mala, E.; Vokurkova, D.; Krcmova, I.; Pliskova, L.; Stepanova, V.; Bartos, V.; Koblizek, V.; Tacheci, I.; Bures, J.; Brozik, J. (Hradec Kralove); Litzman, J. (Brno) 
Official Journal of the

Collegium Internationale Allergologicum

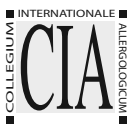

\section{International Archives of Allergy
Immunology}

Founded 1950 by D. Harley, P. Kallós, W. Löfler and F.W. Wittich Continued by E.A. Brown (1952-1954), W. Kaufman (1955-1967), F. Hahn (1961-1972), H.C. Goodman (1963-1975),

R.R.A. Coombs (1955-1984), Z. Trnka (1972-1987), P. Kallós (1950-1988), G.B. West (1959-1991), J. Bienenstock (1990-1991), L.Å. Hanson (1981-1991),

K. Kano (1982-1991), F. Milgrom (1965-1991), K. Rother (1982-1991),

G. Wick (1991-1997), B. Grubeck-Loebenstein (1991-1997), D. Kraft (1998-2002)

\section{Editors-in-Chief}

R. Valenta, Vienna

B. Bohle, Vienna

\section{Associate Editors}

K. Blaser, Davos

J. Bousquet, Montpellier

A.W. Burks, Chapel Hill, N.C.

D. Dombrowicz, Lille

H. Garn, Marburg

P. Gevaert, Ghent

T. Jakob, Freiburg

P.M. O'Byrne, Hamilton, Ont.

R. Pawankar, Tokyo

W.F. Pickl, Vienna

A. Radbruch, Berlin

M. Röllinghoff, Erlangen

H. Saito, Tokyo

C.B. Schmidt-Weber, Munich

T. Schwarz, Kiel

W. Thomas, Perth

M. Triggiani, Naples

R. van Ree, Amsterdam

Consulting Editor for Biostatistics

M. Kundi, Vienna

\section{Editorial Board}

W. Aberer, Graz

M. Akdis, Davos

I.J. Ansotegui, Belfast

L.K. Arruda, Ribeirão Preto

C.E. Baena-Cagnani, Cordoba

T. Biedermann, Tübingen

S.C. Bischoff, Stuttgart

$\mathrm{H}$. Breiteneder, Vienna

G.W. Canonica, Genova

M. Capron, Lille

M.D. Chapman, Charlottesville, Va.

K.Y. Chua, Singapore

M. Ebisawa, Kanagawa

E. Fernández-Caldas, Seefeld

F. Ferreira, Salzburg

H. Grönlund, Stockholm

K.T. HayGlass, Winnipeg, Man.

K. Hoffmann-Sommergruber,

Vienna

P.G. Holt, Perth

F. Horak, Vienna

E. Jensen-Jarolim, Vienna

M. Jutel, Wroclaw

D. Kabelitz, Kiel

A. Kapp, Hannover

D. Kraft, Vienna

M. Larché, Hamilton, Ont.

E. Maggi, Florence

R.N. Maini, London

A. Mari, Latina
S.F. Martin, Freiburg

M. Maurer, Berlin

F. Melchers, Basel

N.G. Papadopoulos, Athens

O. Pérez, Havana City

W.J. Pichler, Bern

T.A.E. Platts-Mills,

Charlottesville, Va.

H. Renz, Marburg/Lahn

N. Rezaei, Teheran

L.J. Rosenwasser, Kansas City, Mo.

K. Roux, Tallahassee, Fla.

J.-M. Saint-Rémy, Leuven

H.A. Sampson, New York, N.Y.

R. Sepiashvili, Moscow

Y. Shoenfeld, Tel Hashomer

H.-U. Simon, Bern

J. Smolen, Vienna

Z. Szépfalusi, Vienna

E. Toubi, Haifa

P. Valent, Vienna

M. van Hage, Stockholm

D.V. Wallace, Fort Lauderdale, Fla.

H. Wekerle, Martinsried

T. Werfel, Hannover

G. Wick, Innsbruck

M. Wickman, Stockholm

U. Wiedermann, Vienna

S. Wöhrl, Vienna

H. Yssel, Montpellier 


\section{Allergy $_{\text {and }}$ Immunology}

International Archives of Allergy and Immunology appears monthly and provides a forum for publication of work from all aspects of modern allergology and immunology. Papers considered of special interest will be treated as 'hot topics' and every attempt will be made to publish these especially fast. The Editor-in-Chief, the Managing Editor and a team of internationally established Associate Editors competently covering all fields of allergology and immunology are responsible for the scientific quality of this international core journal. International Archives publishes original work in the fields of allergy, immunopathology and transplantation, cellular immunology, immunogenetics, immunopharmacology and immunoendocrinology, mucosal immunity, immunology of infectious diseases and immunology of connective tissue diseases. In addition, reviews, minireviews, commentaries and opinions on controversial subjects are published regularly. A new system of manuscript submission, reviewing and processing guarantees competent and fair reviewing as well as fast and high quality publication.

\section{Submission}

Only papers written in English are considered. Detailed Online Submission Instructions with a link to the Submission Website are at http://www.karger.com/iaa/. Before submitting your manuscript, you are encouraged to review the detailed guidelines at www.karger.com/ iaa_guidelines for specific directions as how to get a manuscript ready for submission. If you should have any problems with your submission, or should you feel the need to submit the paper in a non-electronic form, please contact the editorial office:

S. Karger AG

Editorial Office 'International Archives of

Allergy and Immunology'

PO Box

CH-4009 Basel (Switzerland)

Tel. $\quad+41613061360$

Fax +41613061434

E-Mail e.lieberherr@karger.com

Mailing address for courier deliveries only:

Allschwilerstr. 10

CH-4055 Basel (Switzerland)

Original papers: Submitted manuscripts should be fully documented reports of original research. They must describe significant and original observations to be critically evaluated and, if necessary, repeated.

Short communications: These manuscripts should not contain more than 2 printed pages (i.e. 6,460 charactersper page), including an abstract, essential references and not more than 3 tables or figures. Such communications should represent complete, original studies and should be arranged in the same way as full-length manuscripts.

Novel Insights from Clinical Practice (formerly Case Reports): The publication space available for case reports is very limited. The journal only considers case reports with significant new insights or with an extremely unusual and memorable course. Highlighted boxes containing one or two bullet points on 'Established facts' (what is already known) and 'Novel insights' (what new information has been gained) are required and should be placed on the first page of the report. These should be selected so as to reinforce the novelty of the clinical observation. The manuscript should be presented with an abstract (unstructured, max. 200 words), followed by introduction, case report and discussion. Maximum 3 figures.

Review articles, minireviews, opinion articles, controversies and commentaries: Authors who wish to contribute a manuscript to one of these categories should contact the Editor-in-Chief. Minireviews should be focused, brief reports on topics of current interest. Commentaries should offer a more personalized perspective on a topic that will be of interest to the general readership. All contributions to these categories will be subject to Editorial review.

Letters to the Editor concerning work published in the journal may be submitted. They should not exceed 2 manuscript pages including one table or figure.

\section{Conditions}

All manuscripts are subject to editorial review. Manuscripts are received with the explicit understanding that they are not under simultaneous consideration by any other publication. A cover letter with the name, address, and telephone and telefax numbers of the corresponding author must accompany each manuscript. This letter must include a statement that affirms that all authors agree with the submission. Submission of an article for publication implies the transfer of the copyright from the author to the publisher upon acceptance. Accepted papers become the permanent property of International Archives of Allergy and Immunology and may not be reproduced by any means, in whole or in part, without the written consent of the publisher. It is the author's responsibility to obtain permission to reproduce illustrations, tables, etc. from other publications. One of the criteria considered in reviewing manuscripts is the proper treatment of animals. In particular, the use of painful or otherwise noxious stimuli must be carefully and thoroughly justified. Papers that do not meet these criteria will not be accepted for publication.

\section{Conflict of Interest}

Authors are required to disclose any sponsorship or funding arrangements, including that from companies, relating to their research. All authors should disclose any possible conflicts of interest in the cover letter to the editor and at the end of the article.

\section{Plagiarism Policy}

Whether intentional or not, plagiarism is a serious violation. We define plagiarism as a case in which a paper reproduces another work with at least $25 \%$ similarity and without citation.

If evidence of plagiarism is found before/after acceptance or after publication of the paper, the author will be offered a chance for rebuttal. If the arguments are not found to be satisfactory, the manuscript will be retracted and the author sanctioned from publishing $\mathrm{pa}$ pers for a period to be determined by the responsible Editor(s).

\section{Arrangement}

Manuscripts should be written in English and be as concise as possible.

Be sure to display line numbers $(1,2,3$, and so forth) in the left margin of the manuscript (line numbering can be added from the Page Setup or Format menu of word processing programs). The line numbering should be continuous throughout the entire manuscript, from the title page through to the final page (i.e., do not begin numbering from 1 again at the top of each page).

Title page: The first page of each paper should indicate a concise title, the authors' full names, affiliations and e-mail addresses, the institute where the work was conducted, and a short title for use as running head.

Full address: The exact postal address of the corresponding author complete with postal code must be given at the bottom of the title page. Please also supply phone and fax numbers, as well as an e-mail address.

Key words: Please supply 3-10 key words in English that reflect the content of the paper.

Abstract: Provide on a separate page an abstract of not more than 250 words. This abstract should consist of four paragraphs, labeled Background, Methods, Results, and Conclusions. They should briefly describe, respectively, the problem being addressed in the study, how the study was performed, the salient results, and what the authors conclude from the results.

The text should be arranged in the following sections: Introduction, Material and Methods, Results, Discussion, Acknowledgement, References.

Footnotes: Avoid footnotes. When essential, they are numbered consecutively and typed at the foot of the appropriate page.

Tables and illustrations: Tables and illustrations (both numbered in Arabic numerals) should be prepared on separate pages. Tables require a heading and figures a legend, also prepared on a separate page. For the reproduction of illustrations, only good drawings and original photographs can be accepted; negatives or photocopies cannot be used. Due to technical reasons, figures with a screen background should not be submitted When possible, group several illustrations on one block for reproduction (max. size $180 \times 223 \mathrm{~mm}$ ) or provide crop marks. Each illustration must be labeled with its number and the author's name. Electronically submitted $\mathrm{b} / \mathrm{w}$ half-tone and color illustrations must have a final resolution of $300 \mathrm{dpi}$ after scaling (final size), line drawings one of $800-1,200$ dpi. Figure files must not be embedded in a document file but submitted separately (see detailed instructions at www.karger.com/iaa/).

\section{Color illustrations}

Online edition: Color illustrations are reproduced free of charge. In the print version, the illustrations are reproduced in black and white. Please avoid referring to the colors in the text and figure legends.

Print edition: Up to 6 color illustrations per page can be integrated within the text at CHF 800.- per page.

Abbreviations: Avoid overuse of abbreviations. Introduce an abbreviation only when the same term occurs three or more times.

\section{KARGER}

E-Mail karger@karger.com www.karger.com
(C) 2014 S. Karger AG, Basel

The Guidelines for Authors are available at: www.karger.com/iaa_Guidelines 
References: In the text identify references by Arabic numerals [in square brackets]. Material submitted for publication but not yet accepted should be noted as [unpublished data] and not be included in the reference list. The list of references should include only those publications which are cited in the text. Do not alphabetize; number references in the order in which they are first mentioned in the text. The surnames of the authors followed by initials should be given. There should be no punctuation other than a comma to separate the authors. Preferably, please cite all authors. Abbreviate journal names according to the Index Medicus system. Also see International Committee of Medical Journal Editors: Uniform requirements for manuscripts submitted to biomedical journals (www.icmje.org).

\section{Examples}

(a) Papers published in periodicals: Sun J, Koto $\mathrm{H}$ Chung KF: Interaction of ozone and allergen challenges on bronchial responsiveness and inflammation in sensitised guinea pigs. Int Arch Allergy Immuno 1997;112:191-195

(b) Papers published only with DOI numbers:

Theoharides TC, Boucher W, Spear K: Serum interleukin-6 reflects disease severity and osteoporosis in mastocytosis patients. Int Arch Allergy Immunol DOI: $10.1159 / 000063858$.

(c) Monographs: Matthews DE, Farewell VT: Using and Understanding Medical Statistics, ed 3, revised. Basel, Karger, 1996.

(d) Edited books: Parren PWHI, Burton DR: Antibodies against HIV-1 from phage display libraries: Mapping of an immune response and progress towards antiviral immunotherapy; in Capra JD (ed): Antibody Engineering. Chem Immunol. Basel, Karger, 1997, vol 65, pp 18-56.

Full address: The exact postal address complete with postal code must be given at the bottom of the title page. Please also supply phone and fax numbers, as well as your e-mail address.
Reference Management Software: Use of EndNote ${ }^{\circledR}$ is recommended for easy management and formatting of citations and reference lists (format setting: Intervirology).

\section{Digital Object Identifier (DOI)}

S. Karger Publishers supports DOIs as unique identifiers for articles. A DOI number will be printed on the title page of each article. DOIs can be useful in the future for identifying and citing articles published online without volume or issue information. More information can be found at www.doi.org.

\section{Supplementary Material}

Supplementary material is restricted to additional data that are not necessary for the scientific integrity and conclusions of the paper. Please note that all supplementary files will undergo editorial review and should be submitted together with the original manuscript. The Editors reserve the right to limit the scope and length of the supplementary material. Supplementary material must meet production quality standards for Web publication without the need for any modification or editing. In general, supplementary files should not exceed $10 \mathrm{Mb}$ in size. All figures and tables should have titles and legends and all files should be supplied separately and named clearly. Acceptable files and formats are: Word or PDF files, Excel spreadsheets (only if the data cannot be converted properly to a PDF file), and video files (.mov, .avi, .mpeg).

\section{Author's Choice ${ }^{\mathrm{TM}}$}

Karger's Author's Choice ${ }^{\mathrm{TM}}$ service broadens the reach of your article and gives all users worldwide free and full access for reading, downloading and printing at www.Karger.com. The option is available for a onetime fee of CHF 3,000.-, which is a permissible cost in grant allocation. More information can be found at www.karger.com/authors_choice.

\section{NIH-Funded Research}

The U.S. National Institutes of Health (NIH) mandates under the NIH Public Access Policy that final, peer- reviewed manuscripts appear in its digital database within 12 months of the official publication date. As a service to authors, Karger submits your manuscript on your behalf to PubMed Central (PMC) immediately upon publication. It usually receives a PMCID within approximately a month and will appear in PMC after 12 months. For those selecting our premium Author's ChoiceTM service, the usual embargo will be overridden, accelerating the accessibility of your work.

\section{Self-Archiving}

Karger permits authors to archive their pre-prints (i.e. pre-refereeing) or post-prints (i.e. final draft postrefereeing) on their personal or institution's servers, provided the following conditions are met: Articles may not be used for commercial purposes, must be linked to the publisher's version, and must acknowledge the publisher's copyright. Authors selecting Karger's Author's Choice ${ }^{\mathrm{TM}}$ feature, however, are also permitted to archive the final, published version of their article, which includes copyediting and design improvements as well as citation links.

\section{Page Charges}

There are no page charges for papers of 5 or fewer printed pages (including tables, illustrations and references). Each additional complete or partial page is charged to the author at CHF 325.-. The allotted size of a paper is 5 printed pages $(6,460$ characters per page), which is equal to approx. 14 manuscript pages including tables, illustrations and references.

\section{Proofs}

Unless indicated otherwise, proofs are sent to the corresponding author and should be returned with the least possible delay. Alterations other than the correction of printer's errors are charged to the author.

\section{Reprints}

Order forms and a price list are sent with the proofs. Orders submitted after the issue is printed are subject to considerably higher prices.

\section{KARGER}

(C) 2014 S. Karger AG, Basel

The Guidelines for Authors are available at: www.karger.com/iaa_Guidelines 


\section{Allergy ${ }_{\text {and }}$ \\ Immunology}

ISSN Print Edition: 1018-2438

ISSN Online Edition: 1423-0097

Journal Homepage: www.karger.com/iaa

Publication Data: International Archives of Allergy and Immunology is published 12 times a year. Volumes 163-165, each with 4 issues, appear in 2014

Copyright: (c) 2014 S. Karger AG, Basel (Switzerland). All rights reserved. No part of this publication may be translated into other languages, reproduced or utilized in any form or by any means, electronic or mechanical, including photocopying, recording, microcopying, or by any information storage and retrieval system, with out permission in writing from the publisher or, in the case of photocopying, direct payment of a specified fee to the Copyright Clearance Center.

Disclaimer: The statements, opinions and data contained in this publication are solely those of the individual authors and contributors and not of the publisher and the editor(s). The appearance of advertisements in the journal is not a warranty, endorsement, or approval of the products or services advertised or of their effectiveness, quality or safety. The publisher and the editor(s) disclaim responsibility for any injury to persons or property resulting from any ideas, methods, instructions or products referred to in the content or advertisements.
Subscription Rates: Subscriptions run for a full calendar year. Prices are given per year. Personal subscription:

Print or Online

CHF 172.-

EUR 141-

USD 172.00

Print+Online combined

EUR 258.-

USD 316.00

postage and handling (added to print and print+online)

CHF 88.80 Europe, CHF 129.60 Overseas

EUR 72.-

USD 117.60

Institutional subscription:

Print or Online

Print+Online combined

CHF 5382.-

EUR 4410.-

CHF 5919.

postage and handling (added to print and print+online)

CHF 111.- Europe, CHF 162.- Overseas

EUR 90.-

USD 147.00
Back Volumes and Single Issues: Information on availability and prices of single print issues and print or electronic back volumes can be obtained from Customer Service atservice@karger.com.

Bibliographic Indices: This journal is regularly listed in bibliographic services, including Current Contents ${ }^{\circledR}$ and PubMed/MEDLINE.

Photocopying: This journal has been registered with the Copyright Clearance Center (CCC), as indicated by the code appearing on the first page of each article. For readers in the US, this code signals consent for copying of articles for personal or internal use, or for the personal or internal use of specific clients, provided that the stated fee is paid per copy directly to

Copyright Clearance Center Inc.

222 Rosewood Drive

Danvers, MA 01923 (USA)

A copy of the first page of the article must accompany payment. Consent does not extend to copying for general distribution, for promotion, for creating new works, or for resale. In these cases, specific written permission must be obtained from the copyright owner,

S. Karger AG, P.O. Box

CH-4009 Basel (Switzerland).

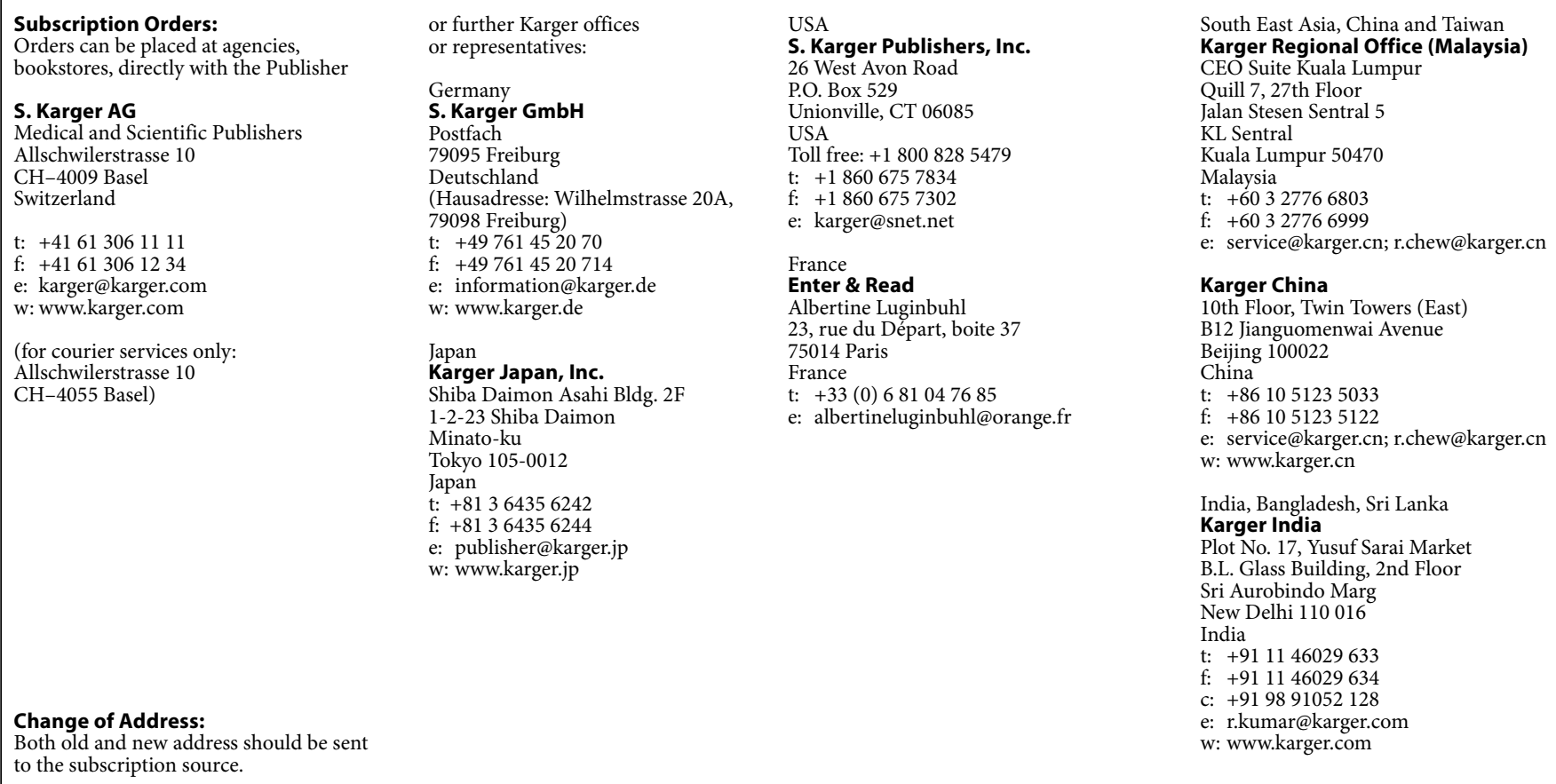

\section{KARGER}

E-Mail karger@karger.com www.karger.com
(C) 2014 S. Karger AG, Basel

The Guidelines for Authors are available at: www.karger.com/iaa_Guidelines 


\section{Contents}

See the journal website for contents

KARGER Basel $\bullet$ Freiburg $\cdot$ Paris $\bullet$ London $\bullet$ New York $\cdot$ New Delhi $•$ Bangkok Beijing $\cdot$ Tokyo $\cdot$ Kuala Lumpur $\cdot$ Singapore $\bullet$ Sydney 


\section{5 th}

International

Meeting on

Angiogenesis

March 12-14, 2014,

Amstelzaal VU University Medical Center, Amsterdam, The Netherlands

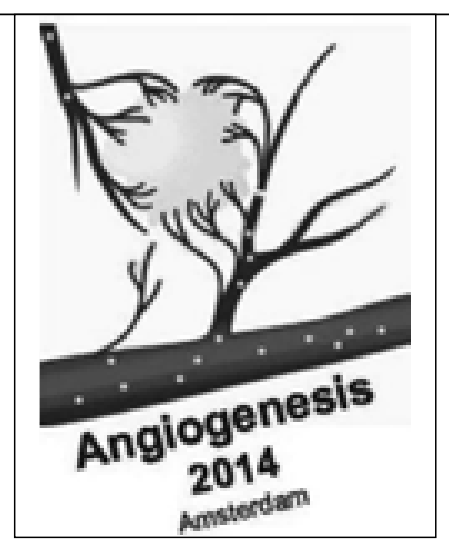

Confirmed speakers:

Carlos Bais

Annette Byrne

Carlijn Bouten

Peter Carmeliet

Gerhard Christofori

James Faber

Marcus Fruttiger

Marie-José Gouwmans

Arjan Griffioen

Rakesh Jain

Gordon Jayson

Robert Kerbel

Bonnie Ky

Diether Lambrechts

José Lopez

Axel Pries

Paul Quax

Niels van Rooyen

Organizing committee:

Stefan Schulte-Merker

Pieter Koolwijk

Henk Verheul

Arjan W. Griffioen

Victor W.M. van Hinsbergh

Dietmar Vestweber

Karin de Visser

Liesbeth de Vries

Mervin Yoder
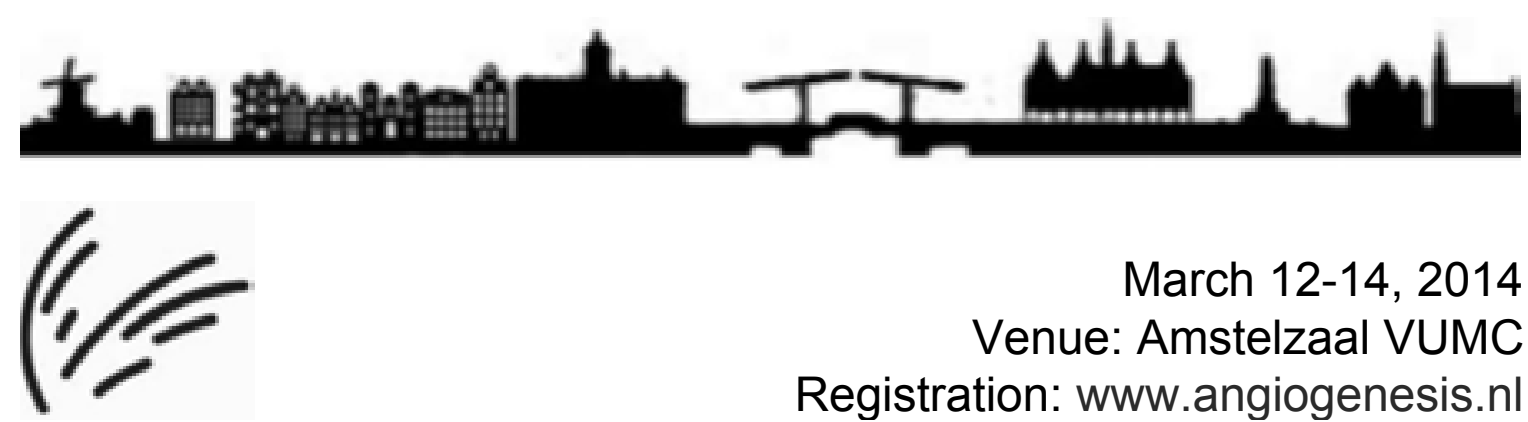

March 12-14, 2014

Venue: Amstelzaal VUMC Registration: www.angiogenesis.nl 


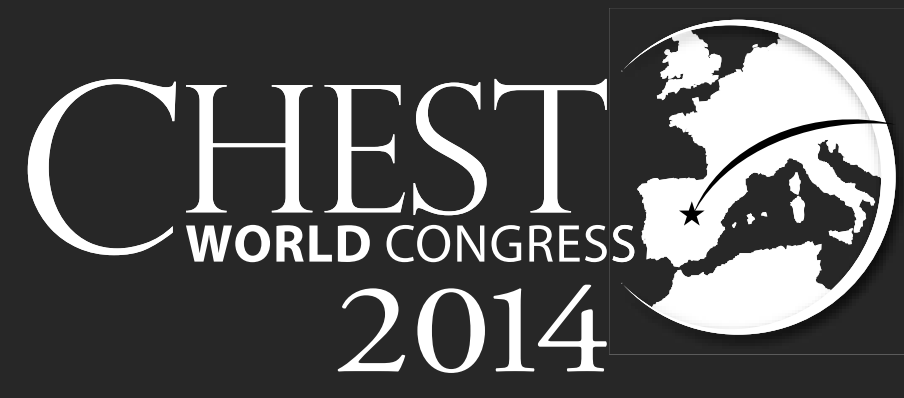

THE GLOBAL

LEADER IN

CLINICAL CHEST

MEDICINE

Save the date for the inaugural

CHEST World Congress

\section{1-24 March 2014 - in Madrid, Spain}

Join the debate on the latest advances in pulmonary clinical practice and patient care.

Submit your late breaking abstract from 1 to 16 December, 2013

Last Chance to Save

Registration is open! Early Registration Opportunity Until 31 December 2013 


\section{(11) 55. Kongress der Deutschen Gesellschaft für Pneumologie und Beatmungsmedizin e.V.}

\section{und 36. Jahrestagung \\ der Gesellschaft für \\ Pädiatrische Pneumologie e.V.

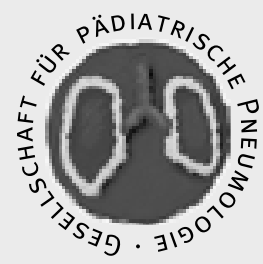

26. - 29. März 2014

Messe und Congress Centrum Bremen

\section{Transition -}

\section{wenn das lungenkranke Kind erwachsen wird}

\section{Kongresspräsident DGP}

Prof. Dr. med. Dieter Ukena

Klinikum Bremen Ost gGmbH

Klinik für Pneumologie und Beatmungsmedizin

Züricher Straße 40

D-28325 Bremen

E-Mail: dieter.ukena@klinikum-bremen-ost.de

Kongresspräsident GPP

Prof. Dr. med. Jürgen Seidenberg

Klinikum Oldenburg gGmbH

Zentrum für Kinder- und Jugendmedizin

Klinik für Pädiatrische Pneumologie und Allergologie,

Neonatologie und Intensivmedizin

Rahel-Straus-Straße 10

D-26133 Oldenburg

E-Mail: paed-pneumologie@klinikum-oldenburg.de

\section{Kongressorganisation}

Agentur KONSENS GmbH

Stockumer Straße 30

D-59368 Werne

Tel.: +49 (0) 2389 / 52 75-0

Fax: +49 (0) 2389 / 52 75-55

E-Mail: dgp@agentur-konsens.de

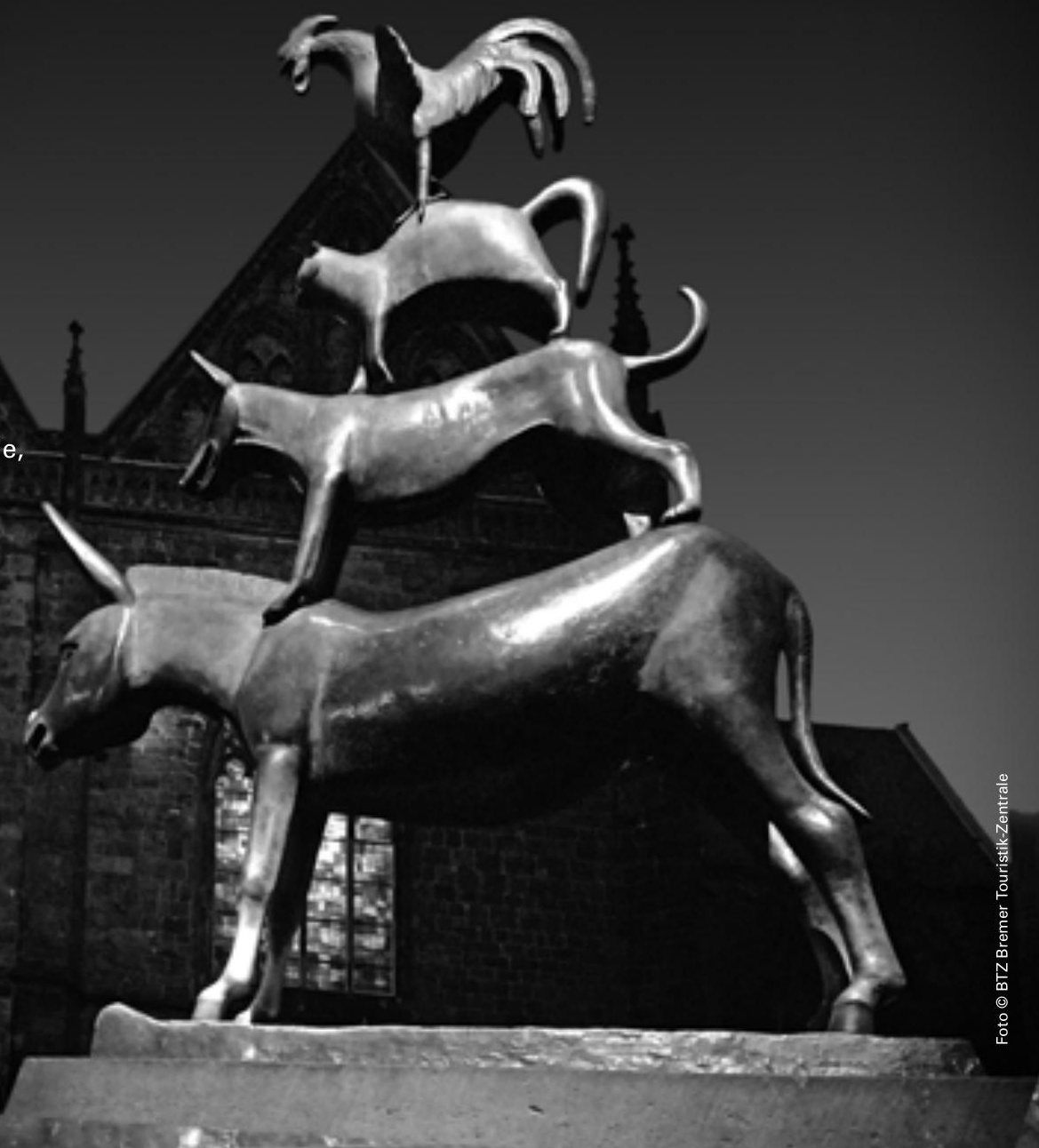




\section{INTERASMA since 1954}
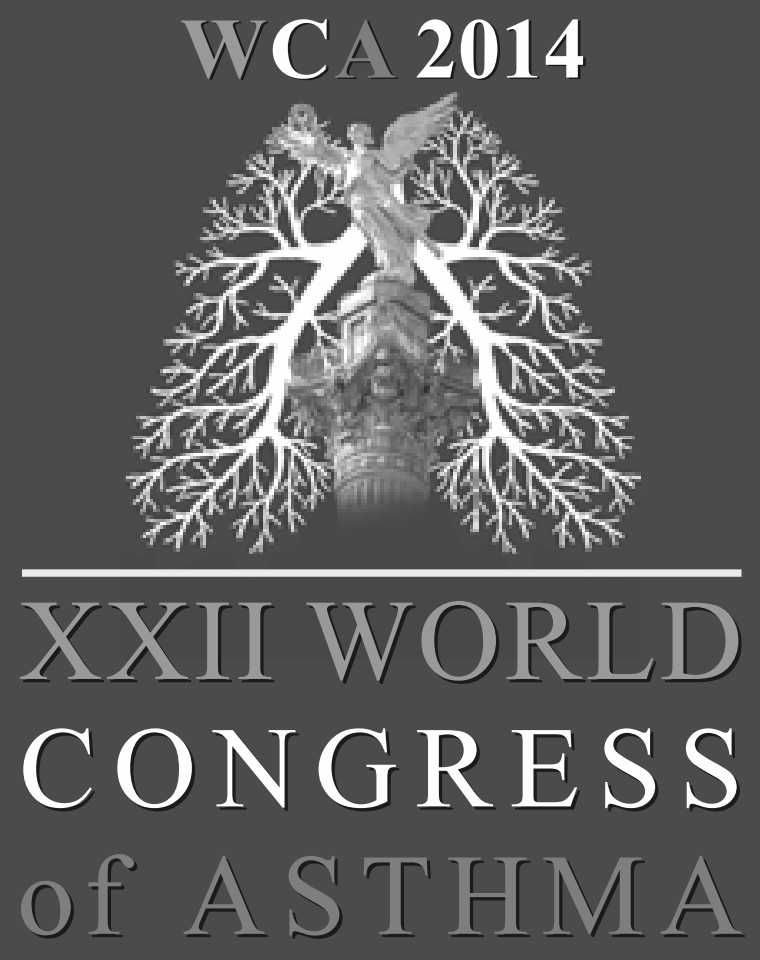

29 March-1 April, 2014

Hilton Mexico City Reforma

Mexico City

\section{In partnership with GINA}

"Translating Science into Clinical Practice"

- Adult: Knowledge translating

- Asthma for Specialists

- Paediatric Programme

WWW.wca-2014.com

\section{Organized by: 0 GLOBAL ASTHMA ASSOCIATION / INTERASMA}

A.M.C. / core P.C.O. 


\section{DHM 2014 9-12 April 2014 Bern, Switzerland}

Drug

Hypersensitivity Meeting

Drug Hypersensitivity Meeting

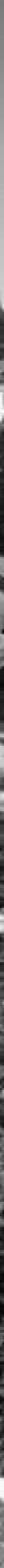

1. 


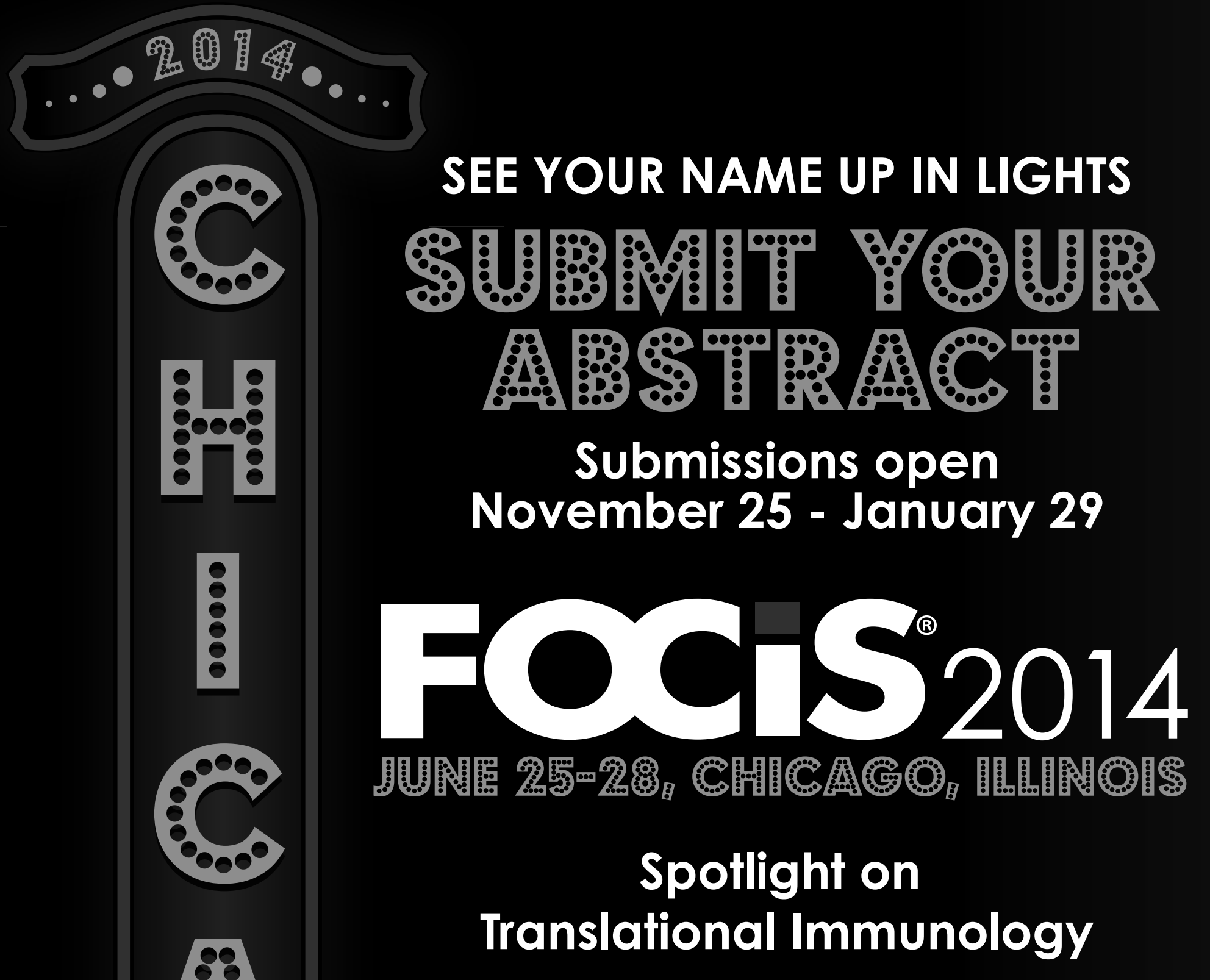




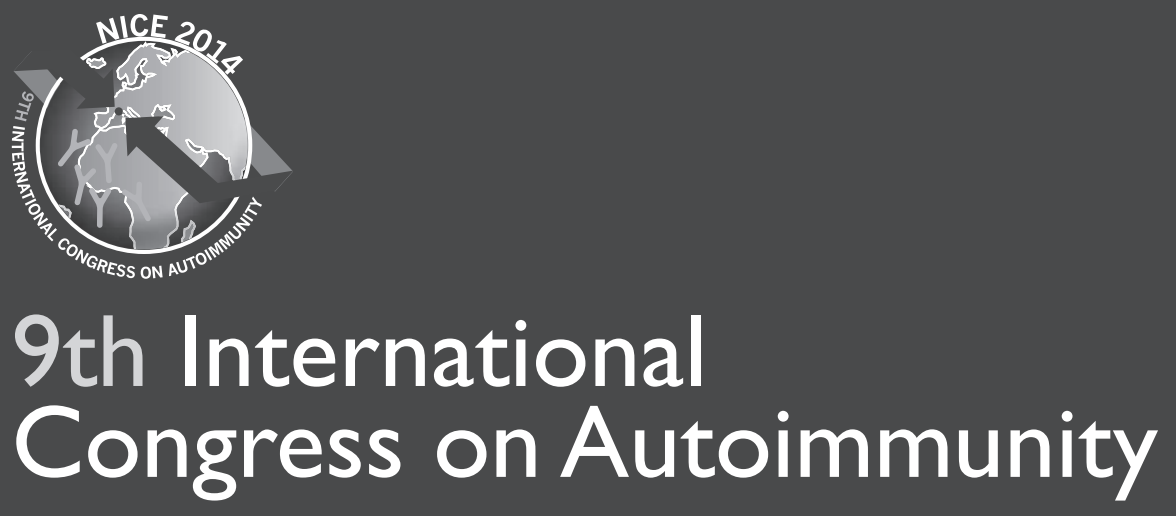

Nice, France | March 26-30, 2014

\section{Register Now}
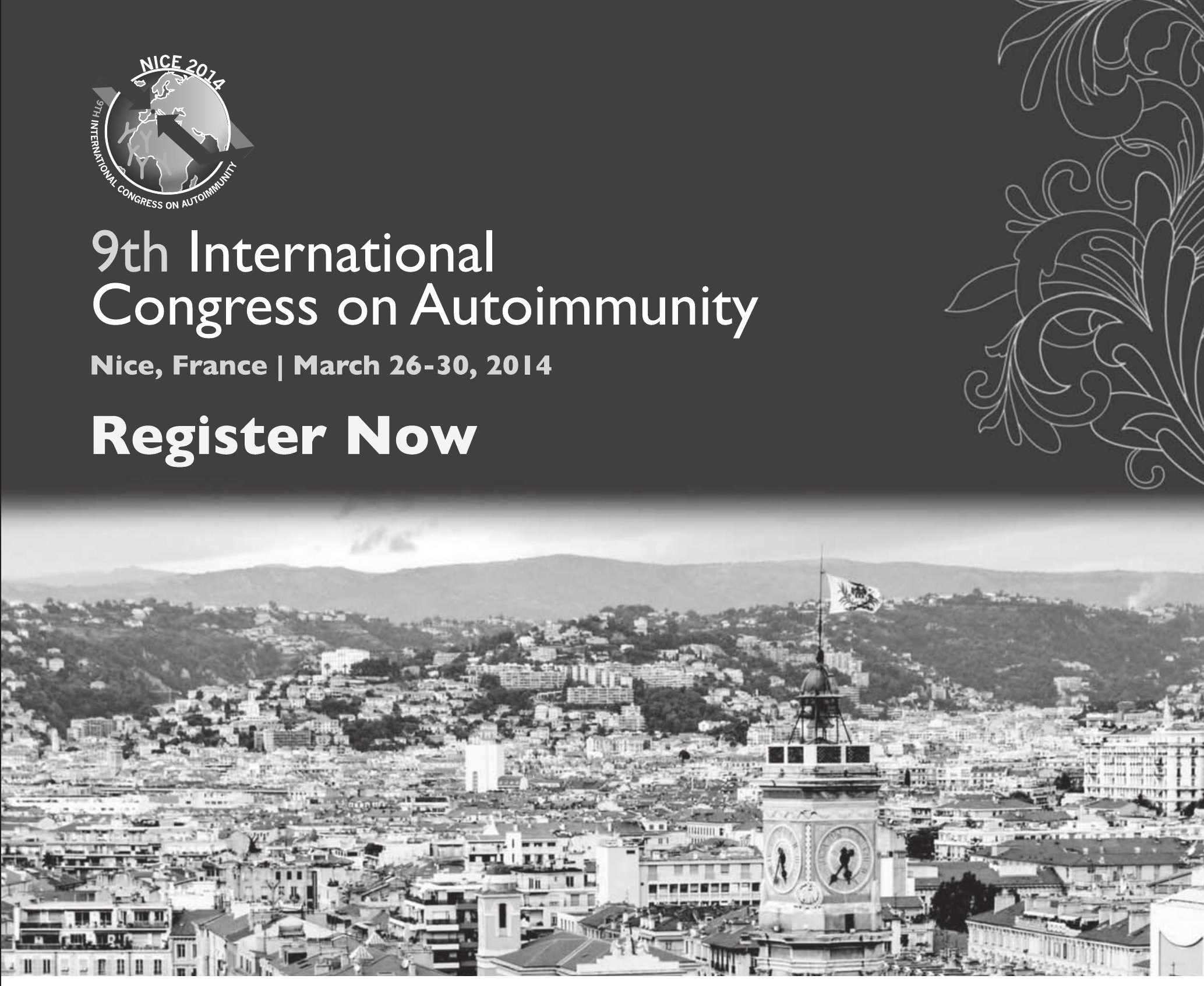

Novel Diagnostic Tools \& New Therapeutic Avenues in Autoimmune Diseases
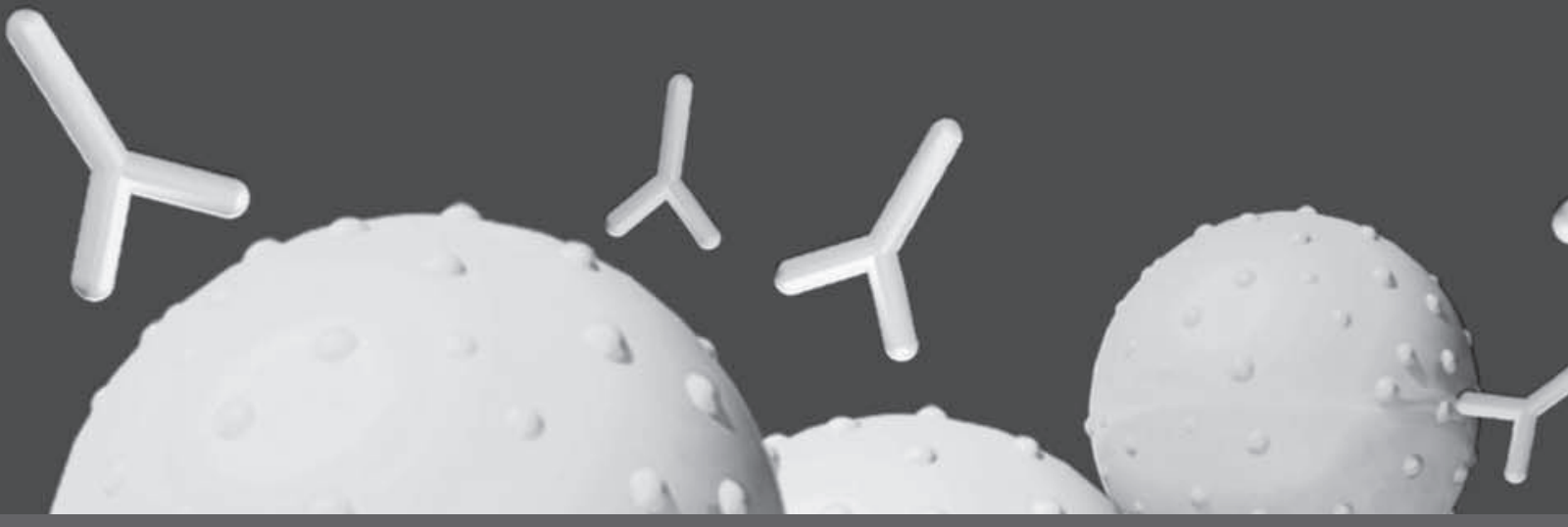

1-3 Rue de Chantepoulet, PO Box $1726, \mathrm{CH}-1211$ Geneva 1 , Switzerland Tel: +4122908 0488, Fax: +41229069140 E-mail: autoimmunity@kenes.com

๑) Kenes Group 2013. All rights reserved. www.kenes.com/autoimmunity

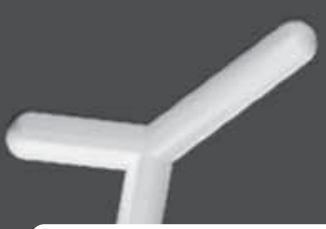

Scan this code with your smart phone:

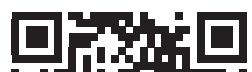
13.

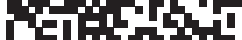

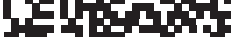

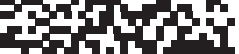
athing

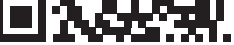




\section{Diseases}

c.] $G$ Inflammatory Bowel Diseases:
Microbiota versus the Barrier
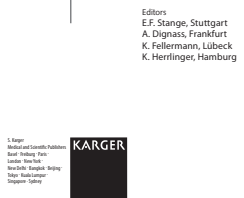

Inflammatory Bowel Diseases: Microbiota versus the Barrier

Editors

E.F. Stange

A. Dignass

K. Fellermann

K. Herrlinger
Inflammatory Bowel Diseases:

Microbiota versus the Barrier

Editors: Stange, E.F. (Stuttgart);

Dignass, A. (Frankfurt); Fellermann, K. (Lübeck);

Herrlinger, K. (Hamburg)

136 p., 25 fig., 14 tab., 2013

CHF 48.- / EUR 40.- / USD 56.00 (soft cover)

CHF 58.- / EUR 48.- / USD 67.00 (online)

Online version for institutional purchase

Prices subject to change

EUR price for Germany, USD price for USA and Latin America only

ISBN 978-3-318-02536-1 (soft cover)

e-ISBN 978-3-318-02537-8

Special Topic Issue:

Digestive Diseases

Vol. 31, No. 3-4 (2013)

Included in subscription

Listed in MEDLINE/PubMed

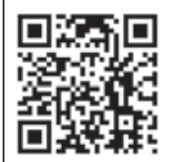

Dear Librarian

I have reviewed this publication and

would like to recommend it for our library.

Recommended by:

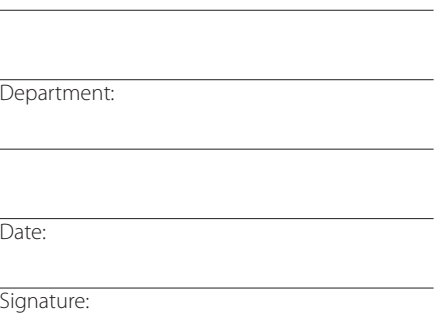

Orders may be placed with any bookshop

subscription agency, directly with the publisher or through a Karger distributor.

\section{Contents}

- Preface: Stange, E.F.

The Gut Microbiota and the Mucosa in IBD

- The History and Philosophy of Inflammatory Bowel

Disease: Rogler, G.

-The Human Gut Microbiome and Its Dysfunctions: Mondot, S.; de Wouters, T.; Doré, J.; Lepage, P.

-The Host and the Flora: Nuding, S.; Antoni, L.; Stange, E.F.

The Gut Barrier in IBD: The First Line of Defense

- Intestinal Stem Cells: Stange, D.E.

-Innate Immune Functions of a-Defensins in the

Small Intestine: Bevins, C.L.

- Mucus and the Goblet Cell: Johansson, M.E.V.;

Hansson, G.C.

- Defective Antibacterial Barrier in Inflammatory Bowel Disease: Klag, T.; Stange, E.F.; Wehkamp, J.

The Gut Barrier in IBD:

The Second Line of Defense

- Innate and Adaptive Immunity in Inflammatory

Bowel Diseases: Foersch, S.; Waldner, M.J.;

Neurath, M.F.

-What Is Wrong with Granulocytes in Inflammatory

Bowel Diseases? Levine, A.P.; Segal, A.W.

- Targeting $T$ and B Lymphocytes in Inflammatory Bowel Diseases: Lessons from Clinical Trials: Gerner, R.R.; Moschen, A.R.; Tilg, H.

\section{Diagnostics and Prognostics in IBD}

- Diagnostics and Prognostics of Inflammatory Bowel Disease with Fecal Neutrophil-Derived Biomarkers Calprotectin and Lactoferrin: Sipponen, $\mathrm{T}$.

- Update Imaging in Inflammatory Bowel Diseases: Herfarth, $\mathbf{H}$.

- Endoscopy as a Prognostic Marker in Inflammatory Bowel Disease: Camus, M.; Pariente, B.; Dray, X.; Allez, M.; Marteau, P.

Differences between Treatment Guidelines in IBD

- Differences between Treatment Guidelines -

Germany: Herrlinger, K.R.

- Comparing Guidelines for the Treatment of Inflammatory Bowel Disease: Hanauer, S.B.; Kirsner, J.B.

- Treatment Guidelines in Inflammatory Bowel Disease: The Japanese Perspectives: Matsuoka, K.; Hibi, T.

\section{Adverse Events}

- Risks of Inflammatory Bowel Disease Treatment with Glucocorticosteroids and Aminosalicylates: Curkovic, l.; Egbring, M.; Kullak-Ublick, G.A.

-Adverse Events of Tumor Necrosis Factor Inhibitors: Fellermann, K.

\section{Treating Microbiota and/or the Barrier}

- Antibiotics and Inflammatory Bowel Diseases: Scribano, M.L.; Prantera, C.

- Probiotics: Kruis, w.

- Lecithin as a Therapeutic Agent in Ulcerative

Colitis: Stremmel, W.; Gauss, A.

- Trichuris suis Ova in Inflammatory Bowel Disease: Schölmerich, J. 